\title{
Peminimalan Beban dan Peminimalan Paksaan Sebagai Cara Berperilaku Santun Dalam Berbahasa Indonesia
}

\author{
Ngusman Abdul Manaf \\ Fakultas Bahasa Sastra dan Seni Universitas Negeri Padang
}

\begin{abstract}
Abstrak: Tujuan penulisan artikel ini adalah mendeskripsikan dan menjelaskan cara penutur bahasa Indonesia berperilaku santun dalam berbahasa Indonesia melalui peminimalan beban dan peminimalan paksaan kepada petutur. Artikel ini ditulis berdasarkan hasil penelitian yang dilakukan di Padang pada tahun 2006. Data penelitian berupa tuturan bahasa Indonesia yang dihasilkan oleh penutur bahasa Indonesia dari berbagai etnis di Indonesia yang berdomisili di Padang. Data penelitian dikumpulkan dengan teknik pengamatan terlibat dan wawancara. Data dianalisis dengan teknik kualitatif yang didasarkan pada teori pragmatik. Hasil penelitian memperlihatkan bahwa peminimalan beban dan peminimalan paksaan kepada petutur yang dilakukan penutur dalam tuturannya menimbulkan dampak pelunakan daya ilokusi sehingga tuturan dirasakan lebih santun oleh petutur.
\end{abstract}

Kata Kunci: tindak tutur, strategi bertutur, peminimalan beban, peminimalan paksaan, pelunakan daya ilokusi, kesantunan berbahasa Indonesia

\begin{abstract}
Indonesia speakers try to be polite in using bahasa Indonesia by minimizing the load and force to the listener. This article written based on research carried out in Padang in 2006. The data of the research was bahasa Indonesia narration from bahasa Indonesia speakers from various ethnics of Indonesia domiciled in Padang. The data collection method were involved observation and interview. Data was analyzed with qualitative method based on pragmatic theory. The result shows that load minimizing and force minimizing to the listener by the speaker in their speech caused illocution softening so that their speech felt politer by the listener.
\end{abstract}

Keyword: speaker behavior, speaker strategy, load minimizing, force minimizing, illocution softening, Bahasa Indonesia politeness.

\section{Pendahuluan}

Tindak tutur tidak hanya berfungsi untuk menyampaikan pesan penutur kepada petutur melainkan juga berfungsi untuk membangun hubungan sosial antara penutur dan petutur. Fungsi yang pertama, penutur berusaha untuk mengungkapkan tuturannya secara singkat dan jelas. Fungsi yang kedua, tuturan sering diungkapkan secara panjang, tidak langsung, dan tidak jelas. Tindak tutur memang mempunyai dua fungsi itu, tetapi kenyataannya, orang sering mengutamakan satu di antara dua fungsi tuturan. Suatu ketika, dalam bertutur, orang mengutamakan sampainya pesan kepada petutur (misalnya, tuturan di dalam tulisan ilmiah). Sebaliknya, pada kesempatan yang lain, orang mengutamakan terbentuknya hubungan sosial antara penutur dan petutur (misalnya, tuturan dalam tegur sapa).

Salah satu cara yang digunakan oleh penutur (termasuk penutur bahasa Minangkabau) untuk 
membangun hubungan sosial dalam proses komunikasi adalah kesantunan berbahasa. Kesantunan berbahasa ada di dalam berbagai bahasa, tetapi cara pengungkapan kesantunan itu khas untuk setiap bahasa. Cara pengungkapan kesantunan yang dimiliki oleh masyarakat digunakan sebagai pedoman untuk bertutur yang santun dan digunakan pula oleh masyarakat penutur bahasa yang bersangkutan untuk menilai kesantunan tuturan orang lain. Cara yang digunakan untuk bertutur yang santun dan cara untuk menilai tingkat kesantunan tuturan orang lain diistilahkan oleh Brown dan Levinson (1987) sebagi strategi kesantunan berbahasa.

Tujuan yang ingin dicapai melalui tulisan ini adalah mendeskripsikan dan menjelaskan cara penutur bahasa Minangkabau berperilaku santun berbahasa Minangkabau melalui peminimalan beban dan peminimalan paksaan kepada petutur. Strategi peminimalan beban kepada petutur dalam bahasa Indonesia menarik untuk diteliti karena strategi itu bersifat produktif dalam pemakaiannya dan bentuknya khas jika dibandingkan dengan bahasa yang lain. Uraian ini diharapkan bermanfaat untuk memperkaya kajian pragmatik khususnya tentang tindak tutur, strategi bertutur, dan kesantunan berbahasa.

\section{Kajian Literatur}

Teori yang digunakan sebagai acuan teoretis dalam menganalisis masalah di dalam tulisan ini adalah teori Pragmatik yang mencakup teori Tindak Tutur, Strategi Bertutur, dan Kesantunan Berbahasa. Teori tindak tutur yang diacu di dalam tulisan ini adalah teori tindak tutur yang diungkapkan oleh Austin (1962) dan Searle (1976). Teori Strategi Bertutur yang diacu di dalam tulisan ini adalah strategi bertutur yang diungkapkan oleh Brown dan Levinson (1987). Teori Kesantunan berbahasa yang diacu di dalam penelitian ini adalah teori Kesantunan Berbahasa yang diungkapkan oleh Brown dan Levinson (1987) dan Leech (1983).

Cara berperilaku santun berbahasa merupakan salah satu objek kajian Pragmatik. Levinson (1983) menjelaskan bahwa pragmatik adalah cabang ilmu bahasa yang membahas pemakaian bahasa di dalam proses komunikasi. Teori pragmatik dipilih sebagai acuan teoretis di dalam tulisan ini, karena Pragmatik dinilai cocok untuk memahami masalah, menganalisis data, membahas hasil analisis data (temuan) tentang cara berperilaku santun berbahasa dalam bahasa Indonesia melalui peminimalan beban kepada petutur. Teori tindak tutur yang diungkapkan oleh Austin (1962) dan Searle (1976) digunakan sebagai acuan teoretis di dalam tulisan ini, karena dianggap memadai untuk mengklasifikasikan tindak tutur yang digunakan oleh penutur dalam berbahasa Indonesia. Teori strategi bertutur yang diungkapkan oleh Brown dan Levinson (1987) digunakan sebagai acuan teoretis di dalam tulisan ini, karena dianggap memadai untuk menjelaskan karakteristik cara peminimalan beban dan paksaan sebagai salah satu bentuk realisasi tindak tutur. Teori kesantunan berbahasa Brown dan Levinson (1987) dan Leech (1983) digunakan sebagai acuan teoretis karena dianggap memadai untuk menjelaskan dampak penggunaan strategi bertutur peminimalan beban dan peminimalan paksaan terhadap kesantunan berbahasa.

Berdasarkan fungsinya, Austin (1962) mengelompokkan tindak tutur menjadi tiga, yaitu 1) lokusi, 2) ilokusi, dan 3) perlokusi. Lokusi adalah tindak tutur yang dilakukan oleh penutur untuk menyampaikan pesan yang pesan penutur itu sama dengan makna leksikal atau makna gramatikal kata-kata yang digunakan untuk mengungkapkan tuturan itu. Dengan kata lain, lokusi digunakan untuk menyampaikan pesan penutur kepada petutur secara harfiah. Ilokusi adalah tindak tutur yang digunakan untuk menyampaikan pesan penutur secara tersirat. Dalam ilokusi, pesan penutur tersembunyi di balik pernyataan yang harfiah. Untuk memahami pesan di dalam ilokusi, petutur perlu menghubungkan tuturan dengan konteks tuturannya. Perlokusi adalah tindak tutur yang digunakan oleh penutur untuk mendapatkan efek tertentu dari petutur. Dalam penelitian ini, pengelompokan tindak tutur menurut Austin ini bermanfaat untuk membedakan tindak tutur yang bersifat harfiah dan tindak tutur yang tidak harfiah atau alih-alih untuk membedakan tindak tutur langsung dan tidak langsung.

Searle (1976) mengelompokkan tindak tutur menjadi 5, yaitu 1) representatif, 2) direktif, 3) ekspresif, 4) komisif, dan 5) deklarasi (bukan deklaratif). Pengelompokan tindak tutur ini 
merupakan reaksi atas pengelompokan tindak tutur yang dilakukan oleh Austin (1969). Searle (1976) menilai pengelompokan tindak tutur, yaitu lokusi, ilokusi, dan perlokusi, yang dilakukan oleh Austin (1969) adalah tumpang-tindih sehingga membingungkan. Pengelompokkan ilokusi dan perlokusi adalah membingungkan, karena ciri khas perlokusi dikatakan tindak tutur itu menimbulkan efek tertentu pada petutur. Menurut Searle, tindak tutur ilokusi juga menimbulkan efek tertentu kepada petutur, misalnya efek benci, takut, senang, dan lain-lain.

Teori kesantunan berbahasa Brown dan Levinson berdasar pada konsep muka (face). Menurut Brown dan Levinson (1987), muka mengacu kepada citra diri. Muka atau citra diri seseorang dapat jatuh. Oleh karena itu, muka perlu dijaga atau dilindungi. Agar muka tidak jatuh, muka perlu dijaga baik oleh pemilik muka itu sendiri maupun orang lain yang sedang berkomunikasi. Salah satu faktor yang berpotensi untuk menjatuhkan muka pelaku tutur adalah tindak tutur. Agar tindak tutur tidak menjatuhkan muka pelaku tutur, tindak tutur perlu dilengkapi dengan peranti penyelamat muka yang berupa kesantunan berbahasa. Muka dikelompokkan menjadi dua, yaitu muka positif dan muka negatif. Muka positif berupa kehendak diri untuk dinilai baik atas semua yang ada pada dirinya atau semua yang dimiliki. Muka negatif berupa kehendak diri untuk dibiarkan bebas melaksanakan apa yang dikehendaki. Perilaku yang santun adalah perilaku yang dapat memenuhi kehendak muka, baik muka positif maupun muka negatif. Karena muka yang perlu dilindungi ada dua jenis, kesantunan berbahasa pun ada dua jenis, yaitu kesantunan positif dan kesantunan negatif. Perilaku santun berbahasa dapat dicapai dengan memilih strategi bertutur sesuai dengan tingkat keterancaman muka pelaku tutur. Tingkat keterancaman muka terutama dihitung berdasarkan dua hal, yaitu 1) perbedaan hubungan kekuasaan (power) $( \pm \mathrm{K})$ antara penutur dan petutur dan 2) tingkat hubungan keakraban atau solidaritas (solidarity) $( \pm S)$ antara penutur dan petutur. Faktor kekuasaan dapat berupa perbedaan umur, perbedaan jabatan, perbedaan pangkat, dan perbedaan peran. Faktor keakraban atau solidaritas dapat berupa lamanya atau sebentarnya seseorang bergaul.
Sejumlah orang telah melakukan penelitian tentang hubungan antara penggunaan strategi bertutur dan kesantunan berbahasa. Orang-orang yang dimaksud adalah Ibrahim (1996), Mualimin (2003), dan Amir, dkk (2006).

Amril dan Ngusman (2006). Perbedaan tulisan ini dengan penelitian terdahulu yang disebutkan di atas adalah tujuan penulisan ini. Tujuan penulisan ini adalah mendeskripsikan dan menjelaskan realisasi strategi peminimalan beban dan peminimalan paksaan dalam tuturan bahasa Indonesia.

\section{Metodologi penelitian}

Data penelitian ini adalah tindak tutur dalam bahasa Indonesia yang dilakukan oleh berbagai anggota kelompok etnis yang ada di Indonesia yang berdomisili di Kota Padang. Yang menjadi informan penelitian ini adalah Penutur Bahasa Indonesia dari anggota kelompok etnis Minangkabau, Melayu Riau, Melayu Jambi, Melayu Bengkulu, Melayu Palembang, Jawa, Batak, Sunda, Betawi, Madura, Bugis, dan Bali. Jumlah subjek penelitian dari setiap kelompok etnis itu adalah minimal tiga orang. Jumlah tiga orang dari setiap kelompok etnis yang disebutkan di atas adalah untuk mengantisipasi jika terjadi perbedaan pandangan tentang kebahasaan di antara informan penelitian, peneliti dapat mengambil keputusan dengan memilih pandangan yang umumnya diikuti oleh anggota kelompok etnis itu.

Pemilihan subjek penelitian dilakukan dengan bertanya kepada anggota kelompok etnis masingmasing tentang siapa anggota kelompok etnisnya yang berdomisili di Sumatera Barat yang merupakan penutur ideal bahasa Indonesia. Atas dasar saran anggota kelompok etnis masingmasing itulah, dipilih subjek penelitian ini.

Data penelitian ini dibatasi pada bahasa lisan yang digunakan untuk berkomunikasi di dalam kehidupan sehari-hari. Data penelitian ini dikumpulkan dengan teknik observasi dan wawancara. Instrumen utama penelitian ini adalah peneliti sendiri yang dilengkapi dengan catatan lapangan. Pengumpulan data tulisan ini dilaksanakan di Padang, Sumatera Barat, selama satu tahun, yaitu mulai bulan Agustus 2005 sampai dengan Juli 2006. Penulis ini berdomisili di Padang dan selama mengumpulkan dan mengolah data, penulis juga berada di tempat penelitian ini, yaitu Padang. 
Pengabsahan data penelitian ini dilakukan dengan teknik perpanjangan pengamatan di lapangan.

Data penelitian dianalisis secara kualitatif dengan enam langkah, yaitu: 1) pemilahan data yang layak diolah dengan data yang tidak layak diolah; 2) inventarisasi data yang dilakukan dengan cara mencatat semua bentuk tuturan yang menggunakan strategi peminimalan beban dan peminimalan paksaan, 3) mengelompokkan bentuk-bentuk tuturan yang menggunakan strategi peminimalan beban dan peminimalan paksaan; 4) mengelompokkan konteks penggunaan strategi peminimalan beban dan peminimalan paksaan menurut model pengelompokkan konteks situasi tutur Brown dan Levinson (1987); 5) menghubung-hubungkan antara tuturan dan konteks tuturannya; dan 6) menarik simpulan sesuai dengan arah yang sudah ditetapkan dalam tujuan penulisan ini.

\section{Hasil Penelitian dan Pembahasan}

Berdasarkan data yang terkumpul, penutur bahasa Indonesia yang berasal dari berbagai kelompok etnis di Indonesia menggunakan strategi peminimalan beban dan peminimalan paksaan sebagai salah satu usaha untuk berperilaku santun dalam berbahasa Indonesia untuk komunikasi di dalam kehidupan sehari-hari. Realisasi strategi peminimalan beban dilakukan dengan cara menggunakan ungkapan 'sedikit' dan 'sebentar' dalam tuturan. Realisasi strategi peminimalan paksaan dilakukan dengan cara menggunakan permintaan bersyarat, rumusan saran, harapan dan pertanyaan dalam tuturan.

Penggunaan strategi peminimalan beban dan peminimalan paksaan didasarkan pada konteks situasi tutur, yang terdiri atas dua parameter utama, yaitu: 1) tingkat perbedaan kekuasaan (power) $( \pm \mathrm{K})$ antara penutur dan petutur; dan 2) tingkat keakraban hubungan atau solidaritas antara penutur dan petutur $( \pm \mathrm{S})$. Kombinasi dua parameter itu membentuk 4 konteks situasi tutur, yaitu a) petutur atau orang yang diajak bicara lebih muda atau lebih rendah kedudukannya dan hubungannya dengan penutur tidak akrab (-K-S); b) petutur lebih muda atau lebih rendah kedudukannya, tetapi hubungannya dengan penutur akrab $(-\mathrm{K}+\mathrm{S}) ; \mathrm{c})$ petutur lebih tua atau lebih tinggi kedudukannya dan hubungannya dengan penutur akrab $(+K+S)$; dan d) petutur lebih tua atau lebih tinggi kedudukannya dan hubungannya dengan penutur tidak akrab (+KS); Untuk melengkapi dan memperjelas uraian ini, disajikan juga uraian dalam konteks situasi tutur (e), yaitu petutur sama usianya atau sama kedudukannya, dan hubungannya dengan penutur akrab $(=\mathrm{K}+\mathrm{S})$.

Temuan penelitian ini yang berupa realisasi strategi peminimalan beban dan peminimalan paksaan dalam tindak tutur dalam bahasa Indonesia untuk komunikasi dalam kegiatan sehari-hari disajikan lebih lanjut berikut ini.

\section{Realisasi Strategi Peminimalan Beban kepada Petutur}

Strategi peminimalan beban kepada petutur ditandai dengan penggunaan ungkapan 'sedikit' dan 'sebentar' di dalam tuturan. Penggunaan ungkapan 'sedikit' dan 'sebentar' dalam tuturan bahasa Indonesia untuk komunikasi dalam kehidupan sehari-hari dapat dilihat dalam contohcontoh tuturan berikut ini.

\section{Penggunaan Ungkapan Sedikit}

Realisasi strategi peminimalan beban dalam bentuk penggunaan ungkapan 'sedikit' dalam tuturan bahasa Indonesia untuk komunikasi sehari-hari dalam berbagai konteks situasi tutur adalah berikut ini: 1) Tolong geser sedikit, Dik. ($\mathrm{K}-\mathrm{S})$; 2) Ketikan dikit, Mat. (-K+S); 3) Bantu dikit, Rin. $(=\mathrm{K}+\mathrm{S})$; 4) Maaf, bisa minta waktu sedikit, Pak? $(+\mathrm{K}-\mathrm{S})$; 5) Maaf Buk, tolong tulisannya dibesarkan sedikit. Kami tidak dapat membaca $(+\mathrm{K}-\mathrm{S})$; 6) Bisa geser dikit, Pak? $(+\mathrm{K}+\mathrm{S})$

Tuturan (1) 'tolong geser sedikit, Dik' ditujukan kepada orang yang lebih muda (-K) dan hubungan antara penutur dan petutur belum akrab. Perististiwa tutur ini berlangsung di atas mobil angkutan kota. Pada tuturan (1), yaitu tuturan yang ditujukan kepada petutur yang belum akrab, cenderung digunakan ungkapan baku 'sedikit', yaitu prefiks se- disertakan dalam ungkapan itu. Untuk membentuk kesantunan tuturan (1), penutur tidak hanya menggunakan strategi peminimalan beban dengan ungkapan sedikit, tetapi penutur juga menggunakan strategi yang lain, yaitu penggunaan sapaan kekerabatan Dik. 
Tuturan (2) 'ketikan dikit, Mat' ditujukan kepada orang yang lebih muda $(-K)$ dan hubungannya dengan penutur sudah akrab (+S). Peristiwa tutur ini berlangsung di sebuah persewaan komputer. Penggunaan ungkapan 'dikit' digunakan untuk meminimalkan beban kepada petutur, sehingga tuturan dirasakan santun oleh petutur. Pada tuturan (2), yaitu tuturan yang ditujukan kepada petutur yang sudah akrab, cenderung digunakan ungkapan ragam tidak baku 'dikit', yaitu prefiks sedilesapkan dalam ungkapan itu.

Tuturan (3) 'Bantu dikit, Rin' ditujukan kepada sesama mahasiswa yang usianya sama $(=K)$ dan hubungannya dengan penutur sudah akrab (+S). Peristiwa tutur ini berlangsung di sebuah rumah kos putri. Tuturan itu diungkapkan ketika penutur akan pulang kampung. Barang-barang yang di bawa pulang banyak. Ketika mobil travel yang ditumpanginya datang, dia meminta tolong kepada kawannya dengan mengungkapkan 'Bantu dikit, Rin'. Dalam tuturan itu, ungkapan 'dikit' digunakan untuk meminimalkan beban kepada petutur, sehingga tuturan dirasakan santun oleh petutur. Pada tuturan (3), yaitu tuturan yang ditujukan kepada petutur yang sudah akrab, cenderung digunakan ungkapan ragam tidak baku 'dikit', yaitu prefiks se- dilesapkan dalam ungkapan itu.

Tuturan (4) 'maaf, bisa minta waktu sedikit, Pak' ditujukan kepada orang yang lebih tua $(+\mathrm{K})$ dan hubungannya dengan penutur belum akrab $(-S)$. Peristiwa tutur ini berlangsung di sebuah ruang kerja dosen sebuah jurusan di Universitas Negeri Padang. Penutur akan berkonsultasi kepada dosen. Penutur menggunakan ungkapan 'sedikit' untuk meminimalkan beban kepada petutur, sehingga tuturan dirasakan santun oleh petutur. Pada tuturan (4), yaitu tuturan yang ditujukan kepada petutur yang belum akrab dan dalam situasi resmi, cenderung digunakan ungkapan ragam baku 'sedikit', yaitu prefiks sedisertakan dalam ungkapan itu. Pada tuturan (4), kesantunan tuturan tidak hanya dibentuk dengan penggunaan ungkapan 'sedikit', tetapi juga digunakan ungkapan yang lain, yaitu permintaan maaf dan penggunaan sapaan kekerabatan 'Pak'.

Tuturan (5) 'maaf Buk, tolong tulisannya dibesarkan sedikit. Kami tidak dapat membaca' ditujukan kepada orang yang usianya lebih muda, tetapi jabatannya lebih tinggi $(+K)$, dan hubungannya dengan penutur tidak akrab (-S). Petutur adalah seorang dosen yang usianya lebih muda. Sebaliknya, penutur adalah mahasiswa (guru yang mengikuti perkulihan program peningkatan kualifikasi pendidikan dari program D-3 ke program S-1), tetapi usianya lebih tua daripada dosennya. Peristiwa tutur ini berlangsung di dalam sebuah ruang kelas dalam proses belajar mengajar. Pada tuturan (5), yaitu tuturan yang ditujukan kepada petutur yang belum akrab dan di dalam situasi resmi, cenderung digunakan ungkapan ragam baku 'sedikit', yaitu prefiks setidak dilesapkan dalam ungkapan itu. Pada tuturan (5), kesantunan tuturan tidak hanya dibentuk dengan penggunaan ungkapan 'sedikit', tetapi juga digunakan ungkapan yang lain, yaitu permintaan maaf, pelunakan perintah dengan menggunakan ungkapan 'tolong' dan penggunaan kata sapaan kekerabatan Buk.

Tuturan (6) 'bisa geser dikit, Pak' ditujukan kepada orang yang lebih tua usianya $(+\mathrm{K})$ dan hubungannya dengan penutur sudah akrab $(+S)$. Peristiwa tutur ini berlangsung di ruang tunggu pasien di Rumah Sakit M. Djamil Padang. Pelaku tutur adalah sesama pasien yang antri di ruang tunggu untuk mendapatkan pelayanan dari dokter. Penutur menggunakan ungkapan 'dikit' untuk meminimalkan beban kepada petutur agar tuturan dirasakan santun oleh petutur. Pada tuturan (6), yaitu tuturan yang ditujukan kepada petutur yang sudah akrab $(+S)$, cenderung digunakan ungkapan ragam tidak baku 'dikit', yaitu prefiks se- dilesapkan dalam ungkapan itu.

\section{Penggunaan Ungkapan Sebentar}

Realisasi strategi peminimalan beban dalam bentuk penggunaan ungkapan 'sebentar' dalam tuturan bahasa Indonesia untuk komunikasi sehari-hari dalam berbagai konteks situasi tutur adalah seperti contoh berikut ini: (7) Bisa pinjam pena sebentar, Dik? (-K-S); (8) Belikan bodrex sebentar, An. $(-\mathrm{K}+\mathrm{S})$; (9) Ke luar sebentar, yok. $(=\mathrm{K}+\mathrm{S})$; (10) Maaf Pak, Bapak diminta menunggu sebentar karena Pak Dekan sedang Rapat. (+KS); (11) Maaf Buk, bagaimana kalau kita istirahat sebentar, Buk? Sudah azan, Buk (+K-S) dan; (12) Buk, permisi sebentar, Buk. Saya mengambil obat $(+\mathrm{K}+\mathrm{S})$. 
Tuturan (7) 'bisa pinjam pena sebentar, Dik' ditujukan kepada orang yang lebih muda $(-K)$ dan hubungan antara penutur dan petutur belum akrab (-S). Peristiwa tutur ini berlangsung di kantor pos. Penutur akan menulis alamat di amplop surat yang akan dikirimkan, tetapi penanya tertinggal. Penutur meminjam pena kepada petutur. Pada tuturan (7), yaitu tuturan yang ditujukan kepada orang yang tidak akrab (S), penutur menggunakan ungkapan 'sebentar' yang digunakan untuk meringankan beban pada petutur agar tuturannya terasa santun. Pembentuk kesantunan berbahasa di dalam tuturan (7) tidak hanya ungkapan 'sebentar', tetapi juga ungkapan yang lain, yaitu kata sapaan kekerabatan Dik.

Tuturan (8) 'belikan bodrex sebentar, $\mathrm{An}^{\prime}$ ditujukan kepada orang yang lebih muda $(-K)$ dan hubungan antara penutur dan petutur akrab (+S). Peristiwa tutur ini berlangsung di rumah. Penutur adalah seorang kakak yang meminta tolong kepada adiknya. Pada tuturan (8), penutur menggunakan ungkapan 'sebentar' yang digunakan untuk meringankan beban pada petutur agar tuturannya terasa santun. Dalam tuturan (8), yaitu tuturan yang ditujukan kepada orang yang sudah akrab $(+S)$, penutur hanya menggunakan satu peranti pembentuk kesantunan berbahasa, yaitu ungkapan peminimalan beban, 'sebentar'.

Tuturan (9) 'ke luar sebentar, yok' ditujukan kepada orang yang sama usianya $(=K)$ dan hubungan antara penutur dan petutur akrab (+S). Peristiwa tutur ini berlangsung di rumah kos. Penutur adalah seorang teman yang meminta tolong kepada temannya yang sama besar dan akrab karena satu angkatan masuk dalam kuliah. Pada tuturan (9) penutur menggunakan ungkapan 'sebentar' yang digunakan untuk meringankan beban pada petutur agar tuturannya terasa santun. Dalam tuturan (9), yaitu tuturan yang ditujukan kepada orang yang sudah akrab, penutur menggunakan satu peranti pembentuk kesantunan berbahasa, yaitu ungkapan peminimalan beban, 'sebentar' dan penutur menggunakan ungkapan ajakan, yok untuk membentuk kesantunan berbahasa.

Tuturan (10) 'Maaf Pak, Bapak diminta menunggu sebentar karena Pak Dekan sedang
Rapat'. ditujukan kepada orang yang lebih tua $(+K)$ dan hubungan antara penutur dan petutur belum akrab (-S). Peristiwa tutur ini berlangsung di kantor fakultas, yaitu di ruang dekan. Karyawan fakultas, bagian penerima tamu berbicara kepada orang yang lebih tua $(+K)$ dan hubungannya belum akrab (-S). Pada tuturan (10), yaitu tuturan yang ditujukan kepada orang yang tidak akrab (S), penutur menggunakan ungkapan 'sebentar' yang digunakan untuk meringankan beban pada petutur agar tuturannya terasa santun. Pembentuk kesantunan berbahasa di dalam tuturan (10) tidak hanya ungkapan 'sebentar', tatapi juga ungkapan yang lain, yaitu 'maaf, Pak/ Bapak', dan alasan 'karena Pak Dekan sedang rapat'.

Tuturan (11) 'maaf Buk, bagaimana kalau kita istirahat sebentar, Buk? Sudah azan, Buk' ditujukan kepada orang yang lebih tinggi jabatannya, tetapi usianya lebih muda $(+K)$ dan hubungan antara penutur dan petutur tidak akrab $(-S)$. Penutur adalah seorang mahasiswa yang berbicara kepada dosennya yang usia dosen itu lebih muda. Peristiwa tutur ini berlangsung di ruang kelas dalam proses belajar mengajar. Pada tuturan (11), yaitu tuturan yang ditujukan kepada orang yang tidak akrab (-S), penutur menggunakan ungkapan 'sebentar' yang digunakan untuk meringankan beban pada petutur agar tuturannya terasa santun. Pembentuk kesantunan berbahasa di dalam tuturan (11) tidak hanya ungkapan 'sebentar', tetapi juga ungkapan yang lain, yaitu 'maaf, Buk, bagaimana kalau', dan alasan 'sudah azan, Buk'.

Tuturan (12) 'Buk, permisi sebentar, Buk. Saya mau mengambil obat' ditujukan kepada orang yang lebih tua $(+K)$ dan hubungan antara penutur dan petutur tidak akrab (-S). Penutur adalah seorang yang sedang bekerja dalam sebuah tim. Tuturan ditujukan kepada ketua tim yang hubungannya akrab dengan penutur. Pada tuturan (12), yaitu tuturan yang ditujukan kepada orang yang hubungannya akrab (+S), penutur menggunakan ungkapan 'sebentar' yang digunakan untuk meringankan beban pada petutur agar tuturannya terasa santun. Pembentuk kesantunan berbahasa di dalam tuturan (12) tidak hanya ungkapan 'sebentar', tetapi juga ungkapan yang lain, yaitu 'Buk, permisi' dan alasan 'mau mengambil obat'. 


\section{Realisasi Strategi Peminimalan Paksaan kepada Petutur}

Strategi peminimalan beban kepada petutur ditandai dengan penggunaan ungkapan 'permintaan bersyarat, rumusan saran, harapan, dan pertanyaan'. Penggunaan ungkapan 'bersyarat, rumusan saran, harapan', dan 'pertanyaan' dalam tuturan bahasa Indonesia untuk komunikasi dalam kehidupan sehari-hari dapat dilihat dalam contoh-contoh tuturan berikut ini.

\section{Penggunaan Permintaan Bersyarat}

Realisasi strategi peminimalan beban dalam bentuk penggunaan permintaan bersyarat dalam tuturan dalam bahasa Indonesia untuk komunikasi sehari-hari dalam berbagai konteks situasi tutur adalah seperti contoh berikut ini: (13) Kalau Ananda tidak keberatan, saya mau menitipkan bagasi saya kepada Ananda karena barang bawaan saya melebihi batas maksimal. ($\mathrm{K}-\mathrm{S})$; (14) Kalau ada waktu, perbaiki atap yang bocor, Di. $(-\mathrm{K}+\mathrm{S})$; (15) Kalau tidak sibuk, ketikan tugas saya, Zal. (=K+S); (16) Maaf Pak, kalau ada waktu, saya ingin konsultasi kepada Bapak. (+KS) dan; (17) Kalau Ibuk tidak keberatan, saya mau ikut kemping menyambut tahun baru. $(+\mathrm{K}+\mathrm{S})$

Tuturan (13) 'kalau Ananda tidak keberatan, saya mau menitipkan bagasi saya kepada Ananda karena barang bawaan saya melebihi batas maksimal' ditujukan kepada orang yang lebih muda $(-\mathrm{K})$ dan hubungan antara penutur dan petutur tidak akrab (-S). Penutur adalah seorang penumpang pesawat di Bandar Udara Internasional Minangkabau yang akan berangkat ke Jakarta dan petutur juga penumpang pesawat dan menuju ke kota tujuan yang sama dengan penutur. Pada tuturan (13), yaitu tuturan yang ditujukan kepada orang yang hubungannya dengan penutur tidak akrab (-S), penutur menggunakan strategi permintaan bersyarat 'kalau Ananda tidak keberatan' untuk meminimalkan paksaan kepada petutur agar tuturannya terasa santun. Pembentuk kesantunan berbahasa di dalam tuturan (13) tidak hanya permintaan bersyarat, tetapi juga ungkapan yang lain, yaitu performatif berpagar 'saya mau'; 'alasan karena barang bawaan saya melebihi batas maksimal', dan kata sapaan 'Ananda'.
Tuturan (14) 'kalau ada waktu, perbaiki atap yang bocor, $\mathrm{Di}^{\prime}$ ditujukan kepada orang yang lebih muda $(-K)$ dan hubungan antara penutur dan petutur akrab $(+S)$. Penutur adalah seorang paman kepada kemenakannya yang sudah lama tinggal di rumah pamannya. Pada tuturan (14), yaitu tuturan yang ditujukan kepada orang yang hubungannya dengan penutur akrab (+S), penutur menggunakan strategi permintaan bersyarat 'kalau ada waktu' untuk meminimalkan paksaan kepada petutur agar tuturannya terasa santun. Pembentuk kesantunan berbahasa di dalam tuturan (14) hanya mengandalkan strategi permintaan bersyarat 'kalau ada waktu'. Untuk bertutur kepada orang yang sudah akrab, penutur cenderung menggunakan sedikit peranti kesantunan berbahasa.

Tuturan (15) 'kalau tidak sibuk, ketikan tugas saya, Zal' ditujukan kepada orang yang sama kedudukannya $(=\mathrm{K})$ dan hubungan antara penutur dan petutur akrab $(+S)$. Penutur adalah seorang teman kepada teman akrabnya. Peristiwa tutur ini terjadi di rumah kos petutur. Pada tuturan (15), yaitu tuturan yang ditujukan kepada orang yang hubungannya dengan penutur akrab $(+S)$, penutur menggunakan strategi permintaan bersyarat 'kalau tidak sibuk' untuk meminimalkan paksaan kepada petutur agar tuturannya terasa santun. Pembentuk kesantunan berbahasa di dalam tuturan (15) hanya mengandalkan strategi permintaan bersyarat 'kalau ada waktu'.

Tuturan (16) 'maaf Pak, kalau ada waktu, saya ingin berkonsultasi kepada Bapak' ditujukan kepada orang yang lebih tua dan lebih tinggi jabatannya $(+K)$ dan hubungan antara penutur dan petutur tidak akrab $(-S)$. Penutur adalah seorang mahasiswa yang berbicara kepada dosennya di ruang kerja dosen di kampus. Pada tuturan (16), yaitu tuturan yang ditujukan kepada orang yang hubungannya dengan penutur tidak akrab (-S), penutur menggunakan strategi permintaan bersyarat 'kalau ada waktu' untuk meminimalkan paksaan kepada petutur agar tuturannya terasa santun. Pembentuk kesantunan berbahasa di dalam tuturan (16) tidak hanya permintaan bersyarat 'kalau ada waktu', tetapi juga ungkapan yang lain, yaitu, permintaan maaf 'maaf', pernyataan keinginan 'saya ingin'; penggunaan kata sapaan 'Pak atau Bapak'. 
Tuturan (17) 'kalau Ibuk tidak keberatan, saya mau ikut kemping menyambut tahun baru' ditujukan kepada orang yang lebih tua dan lebih tinggi jabatannya $(+\mathrm{K})$ dan hubungan antara penutur dan petutur akrab $(+S)$. Penutur adalah seorang anak yang berbicara kepada ibunya di rumah. Pada tuturan (17), yaitu tuturan yang ditujukan kepada orang yang hubungannya akrab $(+S)$, penutur menggunakan strategi permintaan bersyarat 'kalau Ibu tidak keberatan' untuk meminimalkan paksaan kepada petutur agar tuturannya terasa santun. Pembentuk kesantunan berbahasa di dalam tuturan (17) tidak hanya permintaan bersyarat kalau 'Ibuk tidak keberatan', tetapi juga ungkapan yang lain, yaitu penggunaan kata sapaan Ibuk. Jika dibandingkan dengan tuturan yang ditujukan kepada orang yang belum akrab (-S), tuturan yang ditujukan kepada orang yang sudah akrab (+S) lebih sedikit menggunakan peranti pembentuk kesantunan berbahasa daripada tuturan yang ditujukan kepada orang yang tidak akrab (-S).

\section{Penggunaan Rumusan Saran}

Realisasi strategi peminimalan paksaan dalam bentuk penggunaan 'rumusan saran'. Berdasarkan data dalam penelitian ini, rumusan saran dinyatakan dengan ungkapan 'bagaimana kalau' dan 'sebaiknya'. Realisasi strategi peminimalan paksaan dalam tuturan bahasa Indonesia untuk berkomunikasi sehari-hari dalam berbagai konteks situasi tutur adalah seperti contoh berikut: (18) Bagaimana kalau sepeda motor Adik ditepikan karena mobil saya tidak bisa Lewat? (-K-S); (19) Sebaiknya Arif yang mencari lokasi karena dia yang mengenal daerah itu. $(-K+S)$; (20) Sebaiknya kuliahmu selesaikan dulu, baru menikah. $(=\mathrm{K}+\mathrm{S})$; (21) Maaf Pak, bagaimana kalau Bapak tidak merokok di ruangan ber-AC ini? (+K-S); (22) Bagaimana kalau En yang menjadi pembawa acara dalam pembukaan seminar besok? $(+K+P)$.

Tuturan (18) 'Bagaimana kalau sepeda motor Adik ditepikan karena mobil saya tidak bisa lewat' ditujukan kepada orang yang lebih muda $(-K)$ dan hubungan antara penutur dan petutur tidak akrab $(-S)$. Penutur adalah seorang tamu dalam sebuah pesta perkawinan berbicara kepada tamu yang lain. Pada tuturan (18), yaitu tuturan yang ditujukan kepada orang yang hubungannya dengan penutur tidak akrab (-S), penutur menggunakan strategi rumusan saran 'bagaimana kalau sepeda motor Adik ditepikan' untuk meminimalkan paksaan kepada petutur agar tuturannya terasa santun. Pembentuk kesantunan berbahasa di dalam tuturan (18) tidak hanya rumusan saran, tetapi juga ungkapan yang lain, yaitu, alasan 'karena mobil saya tidak bisa lewat', dan kata sapaan kekerabatan 'Adik'..

Tuturan (19) 'sebaiknya Arif yang mencari lokasi' ditujukan kepada orang yang lebih muda (-K) dan hubungan antara penutur dan petutur akrab (+S). Penutur adalah seorang pembina Pramuka yang berbicara kepada anggota Pramuka. Pada tuturan (19), yaitu tuturan yang ditujukan kepada orang yang hubungannya dengan penutur akrab, penutur menggunakan strategi rumusan saran untuk meminimalkan paksaan kepada petutur agar tuturannya terasa santun. Pembentuk kesantunan berbahasa di dalam tuturan (19) tidak hanya strategi rumusan saran, tetapi juga strategi yang lain, yaitu memberikan alasan 'karena dia yang mengenal daerah itu'. Untuk bertutur kepada orang yang sudah akrab, penutur cenderung menggunakan sedikit peranti kesantunan berbahasa.

Tuturan (20) 'sebaiknya kuliahmu selesaikan dulu, baru menikah' ditujukan kepada orang yang sama kedudukannya $(=\mathrm{K})$ dan hubungan antara penutur dan petutur akrab $(+\mathrm{S})$. Penutur adalah seorang teman yang berbicara kepada teman akrabnya. Peristiwa tutur ini terjadi di rumah kos petutur. Pada tuturan (20), yaitu tuturan yang ditujukan kepada orang yang hubungannya dengan penutur akrab $(+S)$, penutur menggunakan strategi rumusan saran 'sebaiknya kuliahmu selesaikan dulu' untuk meminimalkan paksaan kepada petutur agar tuturannya terasa santun. Pembentuk kesantunan berbahasa di dalam tuturan (20) hanya mengandalkan strategi rumusan saran 'sebaiknya kuliahmu selesaikan dulu'.

Tuturan (21) 'maaf Pak, bagaimana kalau Bapak tidak merokok di ruangan ber-AC ini' ditujukan kepada orang yang lebih tua dan lebih tinggi jabatannya $(+K)$ dan hubungan antara penutur dan petutur tidak akrab (-S). Penutur adalah seorang mahasiswa yang menjadi panitia sebuah seminar yang meminta agar seorang 
peserta seminar tidak merokok di ruangan berAC. Pada tuturan (21), yaitu tuturan yang ditujukan kepada orang yang hubungannya dengan penutur tidak akrab $(-S)$, penutur menggunakan strategi rumusan saran, 'bagaimana kalau Bapak tidak merokok di ruangan ber-AC ini' untuk meminimalkan paksaan kepada petutur agar tuturannya terasa santun. Pembentuk kesantunan berbahasa di dalam tuturan (21) tidak hanya rumusan saran, tetapi juga ungkapan yang lain, yaitu permintaan maaf dan penggunaan kata sapaan kekerabatan Pak.

Tuturan (22) 'bagaimana kalau Buk En yang menjadi pembawa acara dalam pembukaan seminar besok' ditujukan kepada orang yang lebih tua $(+K)$, tetapi hubungan antara penutur dan petutur akrab $(+S)$. Penutur adalah seorang seksi acara dalam sebuah kepanitiaan seminar. Pada tuturan (22), yaitu tuturan 'Bagaimana kalau Buk En yang menjadi pembawa acara dalam pembukaan seminar besok' yang ditujukan kepada orang yang hubungannya dengan penutur akrab, penutur menggunakan strategi rumusan saran untuk meminimalkan paksaan kepada petutur agar tuturannya terasa santun. Pembentuk kesantunan berbahasa di dalam tuturan (22) tidak hanya rumusan saran, tetapi juga strategi yang lain, yaitu menggunakan kata sapaan kekrabatan Buk. Jika dibandingkan dengan tuturan yang ditujukan kepada orang yang belum akrab, tuturan yang ditujukan kepada orang yang sudah akrab lebih sedikit menggunakan peranti pembentuk kesantunan berbahasa daripada tuturan yang ditujukan kepada orang yang tidak akrab.

\section{Pengungkapan Harapan}

Strategi peminimalan paksaan direalisasikan dengan pengungkapan harapan dalam bentuk ungkapan ... harap/... berharap. Penggunaan strategi pengungkapan harpan dalam tuturan dalam bahasa Indonesia untuk komunikasi seharihari dalam berbagai konteks situasi tutur adalah seperti contoh berikut ini: (23) Saya harap Adik dapat mengisi angket ini dan mengembalikannya kepada saya tiga hari yang akan datang. (-K-S); (24) Saya harap Zaenal mau menjadi Garin di mesjid ini. $(-K+S)$; (25) Saya harap hari Senin pagi sudah sampai di sini, karena banyak foto kopian yang belum dijilid. $(=\mathrm{K}+\mathrm{S})$; (26) Kami berharap kepada Bapak Walikota agar menindak tegas oknum yang menyelewengkan dana BOS. (+K-S); dan (27) Mul mengharapkan Buk Des untuk menggantikan saya dalam mengajar sehari besok. $(+\mathrm{K}+\mathrm{S})$

Tuturan (23) 'saya harap adik dapat mengisi angket ini dan mengembalikannya kepada saya tiga hari yang akan datang' ditujukan kepada orang yang lebih muda $(-K)$ dan hubungan antara penutur dan petutur tidak akrab (-S). Penutur adalah seorang peneliti yang sedang mengumpulkan data. Pada tuturan (23), yaitu tuturan yang ditujukan kepada orang yang hubungannya dengan penutur tidak akrab, penutur menggunakan strategi pengungkapan harapan 'saya harap' untuk meminimalkan paksaan kepada petutur agar tuturannya terasa santun. Pembentuk kesantunan berbahasa di dalam tuturan (23) tidak hanya menggunakan strategi pengungkapan harapan, tetapi juga ungkapan yang lain, yaitu, penggunaan kata sapaan kekerabatan 'Adik'.

Tuturan (24) 'saya harap Zaenal mau menjadi Garin di mesjid ini' ditujukan kepada orang yang lebih muda (-K) dan hubungan antara penutur dan petutur akrab $(+S)$. Penutur adalah seorang pengurus sebuah mesjid meminta kepada salah seorang mahasiswa untuk menjadi garin (penjaga mesjid) di sebuah mesjid. Pada tuturan (24), yaitu tuturan yang ditujukan kepada orang yang hubungannya dengan penutur akrab, penutur menggunakan strategi rumusan saran untuk meminimalkan paksaan kepada petutur agar tuturannya terasa santun. Pembentuk kesantunan berbahasa di dalam tuturan (24) tidak hanya strategi pengungkapan harapan, tetapi juga strategi yang lain, yaitu penyapaan nama diri Zaenal sebagai penanda keakraban.

Tuturan (25) 'saya harap Adi sudah sampai di sini hari Senin pagi, karena banyak foto kopian yang belum dijilid' ditujukan kepada orang yang sama kedudukannya $(=\mathrm{K})$ dan hubungan antara penutur dan petutur akrab $(+S)$. Penutur adalah seorang karyawan foto kopi kepada teman akrabnya sesama karyawan foto kopi. Pada tuturan (25), yaitu tuturan yang ditujukan kepada orang yang hubungannya dengan penutur akrab $(+S)$, penutur menggunakan strategi pengungkapan harapan untuk meminimalkan paksaan kepada 
petutur agar tuturannya terasa santun. Pembentuk kesantunan berbahasa di dalam tuturan (25) tidak hanya menggunakan strategi pengungkapan harapan, tetapi juga menggunakan strategi penyebutan nama diri Adi sebagai penanda keakraban.

Tuturan (26) 'kami berharap kepada Bapak Walikota agar menindak tegas oknum yang menyelewengkan dana BOS' ditujukan kepada orang yang lebih tua dan lebih tinggi jabatannya (+K) dan hubungan antara penutur dan petutur tidak akrab (-S). Penutur adalah seorang peserta seminar tentang Kebijakan di Bidang Pendidikan di Indonesia yang menyampaikan harapannya kepada Walikota. Pada tuturan (26), yaitu tuturan yang ditujukan kepada orang yang hubungannya dengan penutur tidak akrab, penutur menggunakan strategi pengungkapan harapan untuk meminimalkan paksaan kepada petutur agar tuturannya terasa santun. Pembentuk kesantunan berbahasa di dalam tuturan (26) tidak hanya rumusan saran, tetapi juga ungkapan yang lain, yaitu penggunaan kata sapaan kekerabatan Bapak.

Tuturan (27) 'Mul mengharapkan Buk Des untuk menggantikan saya dalam mengajar sehari besok' ditujukan kepada orang yang lebih tua $(+\mathrm{K})$, tetapi hubungan antara penutur dan petutur akrab (+S). Penutur adalah seorang guru sekolah dasar yang sedang berbicara kepada kawannya sesama guru. Peristiwa tutur ini berlangsung di ruang kantor guru. Pada tuturan (27), penutur menggunakan 'strategi pengungkapan harapan' untuk meminimalkan paksaan kepada petutur agar tuturannya terasa santun. Pembentuk kesantunan berbahasa di dalam tuturan (27) tidak hanya rumusan saran, tetapi juga strategi yang lain, yaitu menggunakan kata sapaan kekerabatan Buk. Jika dibandingkan dengan tuturan yang ditujukan kepada orang yang belum akrab, tuturan yang ditujukan kepada orang yang sudah akrab lebih sedikit menggunakan peranti pembentuk kesantunan berbahasa daripada tuturan yang ditujukan kepada orang yang tidak akrab.

\section{Penggunaan Pertanyaan}

Realisasi strategi peminimalan paksaan dalam bentuk 'penggunaan pertanyaan' dalam tuturan dalam bahasa Indonesia untuk komunikasi sehari- hari dalam berbagai konteks situasi tutur adalah seperti contoh berikut: (28) Apakah Adik bawa korek api?(-K-S); (29) Apakah Syafril bisa ngantar saya ke BIM? (-K+S); (30) Arif dapat menerjemahkan buku ini? (=K+S); (31) Maaf Buk, apakah Ibuk mau meminjamkan buku Analisis Wacana kepada kami. Kami sudah mencari, tetapi kami tidak menemukan buku itu. (+K-S); dan (32) Apakah Pak Ali dapat mengusahakan pakaian tim bola voli untuk kami? $(+\mathrm{K}+\mathrm{S})$.

Tuturan (28) 'apakah Adik bawa korek api' ditujukan kepada orang yang lebih muda (-K) dan hubungan antara penutur dan petutur tidak akrab (-S). Penutur adalah seorang penonton sepak bola yang berbicara kepada orang yang baru dikenal yang sama-sama menonton sepak bola di Lapangan Imam Bonjol Padang (-S). Pada tuturan (28), yaitu tuturan yang ditujukan kepada orang yang hubungannya dengan penutur tidak akrab (-S), penutur menggunakan strategi rumusan pertanyaan 'apakah Adik bawa korek api' untuk meminimalkan paksaan kepada petutur agar tuturannya terasa santun. Pembentuk kesantunan berbahasa di dalam tuturan (28) tidak hanya strategi rumusan pertanyaan, tetapi juga ungkapan yang lain, yaitu penggunaan kata sapaan kekerabatan 'Adik'.

Tuturan (29) 'apakah Syafril bisa ngantar saya ke BIM' ditujukan kepada orang yang lebih muda (-K) dan hubungan antara penutur dan petutur akrab (+S). Penutur adalah seorang dosen yang lebih tua kepada dosen yang lebih muda. Pada tuturan (29), yaitu tuturan yang ditujukan kepada orang yang hubungannya dengan penutur akrab, penutur menggunakan strategi rumusan pertanyaan untuk meminimalkan paksaan kepada petutur agar tuturannya terasa santun. Pembentuk kesantunan berbahasa di dalam tuturan (29) tidak hanya strategi rumusan pertanyaan, tetapi juga strategi yang lain, yaitu penyapaan nama diri Syafril sebagai penanda keakraban.

Tuturan (30) 'Arif dapat menerjemahkan buku ini' ditujukan kepada orang yang sama kedudukannya $(=\mathrm{K})$ dan hubungan antara penutur dan petutur akrab $(+S)$. Penutur adalah seorang mahasiswa Jurusan Bahasa dan Sastra Indonesia FBSS, Universitas Negeri Padang yang berbicara kepada temannya yang berasal dari bahasa 
Inggris. Pada tuturan (30), yaitu tuturan yang ditujukan kepada orang yang hubungannya dengan penutur akrab $(+S)$, penutur menggunakan strategi rumusan pertanyaan untuk meminimalkan paksaan kepada petutur agar tuturannya terasa santun. Pembentuk kesantunan berbahasa di dalam tuturan (30) tidak hanya menggunakan strategi pengungkapan harapan, tetapi juga menggunakan strategi penyebutan nama diri Arif sebagai penanda keakraban.

Tuturan (31) 'maaf Buk, apakah Ibuk mau meminjamkan buku Analisis Wacana kepada kami; kami sudah mencari, tetapi kami tidak menemukan buku itu' ditujukan kepada orang yang lebih tua dan lebih tinggi jabatannya $(+K)$ dan hubungan antara penutur dan petutur tidak akrab (-S). Penutur adalah seorang mahasiswa yang berbicara kepada dosennya saat akhir perkuliahan. Pada tuturan (31), yaitu tuturan yang ditujukan kepada orang yang hubungannya dengan penutur tidak akrab, penutur menggunakan strategi rumusan pertanyaan untuk meminimalkan paksaan kepada petutur agar tuturannya terasa santun. Pembentuk kesantunan berbahasa di dalam tuturan (31) tidak hanya rumusan saran, melainkan juga ungkapan yang lain, yaitu penggunaan kata sapaan kekerabatan Ibuk, permintaan maaf, dan pemberian alasan 'sudah mencari, tetapi kami tidak menemukan buku itu'.

Tuturan (32) 'apakah Pak Ali dapat mengusahakan pakaian tim bola voli untuk kami' ditujukan kepada orang yang lebih tua, tetapi hubungan antara penutur dan petutur akrab $(+K)$. Penutur adalah seorang pemuda di sebuah kelurahan yang berbicara kepada ketua pemuda. Peristiwa tutur ini berlangsung di lapangan bola voli. Pada tuturan (32), yaitu tuturan yang ditujukan kepada orang yang hubungannya dengan penutur akrab, penutur menggunakan strategi rumusan pertanyaan 'apakah Pak Ali dapat mengusahakan pakaian tim bola voli untuk kami' untuk meminimalkan paksaan kepada petutur agar tuturannya terasa santun. Pembentuk kesantunan berbahasa di dalam tuturan (32) tidak hanya strategi rumusan pertanyaan, melainkan juga strategi yang lain, yaitu menggunakan kata sapaan kekerabatan Buk dan penyebutan nama Ali. Jika dibandingkan dengan tuturan yang ditujukan kepada orang yang belum akrab, tuturan yang ditujukan kepada orang yang sudah akrab lebih sedikit menggunakan peranti pembentuk kesantunan berbahasa daripada tuturan yang ditujukan kepada orang yang tidak akrab.

\section{Pembahasan}

Bagian pembahasan ini berisi penjelasan tentang temuan dalam tulisan ini dan penjelasan tentang kedudukan temuan dalam tulisan ini di antara hasil penelitian terdahulu yang terkait. Hasil kajian ini dibahas berdasarkan teori tindak tutur, strategi bertutur, dan kesantunan berbahasa. Temuan dalam tulisan ini yang dibahas adalah realisasi penggunaan strategi peminimalan beban dan peminimalan paksaan dalam tindak tutur dalam bahasa Indonesia untuk komunikasi sehari-hari. Temuan itu dibahas satu persatu berikut ini.

\section{Peminimalan Beban kepada Petutur}

Strategi peminimalan beban kepada petutur direalisasikan dalam bentuk penggunaan ungkapan 'sedikit' dan 'sebentar' dalam tuturan bahasa Indonesia. Strategi peminimalan beban kepada penutur ini digunakan untuk membentuk tuturan yang santun. Ungkapan 'sedikit' dan 'sebentar' digunakan dalam situasi tutur dengan tingkat keterancaman muka tinggi sampai dengan rendah, sesuai dengan urutan berikut ini: (1) (+KS) petutur lebih berkuasa dan tidak akrab, (2) $(+\mathrm{K}+\mathrm{S})$ petutur lebih berkuasa, tetapi akrab, (3) $(-\mathrm{K}-\mathrm{S})$ petutur lebih rendah kekuasaannya tetapi tidak akrab, dan $(-K+S)$ petutur lebih rendah kekuasaannya dan sudah akrab.

Penggunaan ungkapan 'sedikit' seperti dalam tuturan 'bantu sedikit, Rin' dan penggunaan ungkapan 'sebentar' seperti dalam tuturan 'belikan bodrex sebentar, $\mathrm{An}^{\prime}$ adalah upaya penutur untuk tidak membebani atau meminimalkan beban kepada petutur. Bagi orang Indonesia (setidak-tidaknya menurut informan tulisan ini), tindakan tidak membebani orang lain atau tidak merepotkan orang lain adalah tindakan yang baik dan bernilai santun. Berdasarkan konsep skala untung-rugi yang diungkapkan oleh Leech (1983), jika tuturan semakin sedikit merugikan petutur (orang yang diajak bicara), maka tuturan itu 
semakin bernilai santun. Sebaliknya, jika tuturan semakin banyak merugikan petutur, maka tuturan itu semakin tidak santun. Dari sisi lain, berdasarkan konsep strategi bertutur dan tingkat keterancaman muka pelaku tutur yang diungkapkan oleh Brown dan Levinson (1987), penggunaan ungkapan peminimalan beban menimbulkan efek pelunakan daya ilokusi, sehingga tuturan dirasakan santun oleh petutur.

\section{Peminimalan Paksaan kepada Petutur}

Penutur berusaha meminimalkan paksaan kepada petutur dengan cara sebagai berikut: permintaan bersyarat seperti dalam tuturan 'kalau ada waktu, perbaiki atap yang bocor, $\mathrm{Di}^{\prime}$; rumusan saran seperti dalam tuturan 'sebaiknya Arif yang mencari lokasi, karena dia yang mengenal daerah itu'; harapan seperti dalam tuturan 'saya harap Zaenal mau menjadi Garin di mesjid ini'; dan pertanyaan seperti dalam tuturan 'apakah Syafril bisa ngantar saya ke BIM'. Penggunaan ungkapan bersyarat, rumusan saran, harapan, dan pertanyaan dalam tuturan adalah usaha penutur untuk meminimalkan paksaan kepada petutur. Bagi orang Indonesia pada umumnya, perilaku tidak memaksa orang lain adalah sikap yang baik dan bernilai santun. Berdasarkan konsep skala pilihan (banyak pilihan-tidak ada pilihan) yang diungkapkan oleh Leech (1983), bahwa tuturan yang semakin banyak memberikan alternatif pilihan kepada petutur (orang yang diajak bicara), maka tuturan itu semakin bernilai santun. Sebaliknya, tuturan yang semakin sedikit memberikan alternatif pilihan kepada petutur, maka tuturan itu semakin tidak santun. Tuturan yang semakin banyak memberikan alternatif pilihan bersifat tidak memaksa petutur, sehingga tuturan dirasakan santun oleh petutur. Sebaliknya, tuturan yang tidak memberikan alternatif pilihan kepada petutur adalah bersifat memaksa, sehingga tuturan dirasakan tidak santun oleh petutur. Dari sisi lain, berdasarkan konsep strategi bertutur dan tingkat keterancaman muka pelaku tutur yang diungkapkan oleh Brown dan Levinson (1987), ungkapan peminimalan paksaan kepada petutur menimbulkan efek pelunakan daya ilokusi, sehingga tuturan dirasakan santun oleh petutur.

Dalam sebuah tuturan, tidak hanya digunakan strategi peminimalan beban atau peminimalan paksaan, tetapi strategi itu juga digabungkan dengan strategi yang lain. Misalnya, permintaan maaf, penggunaan kata sapaan kekerabatan, alasan atau yang lain seperti tuturan sebagai berikut: (1) 'maaf Pak, Bapak diminta menunggu sebentar karena Pak Dekan sedang rapat; (2) maaf Pak, bagaimana kalau Bapak tidak merokok di ruangan ber-AC ini. Dalam konteks situasi tutur yang tingkat keterancaman muka tinggi, yaitu petutur lebih berkuasa dan tidak akrab dengan penutur (+K-S) banyak menggunakan peranti kesantunan berbahasa dalam tuturan. Sebaliknya, dalam konteks situasi tutur yang tingkat keterancaman muka rendah, yaitu kekuasaan petutur lebih rendah dan belum akrab dengan penutur $(-K+S)$, cenderung digunakan tuturan yang sedikit menggunakan peranti kesantunan berbahasa. Temuan dalam tulisan ini dapat dijelaskan dengan konsep penyelamatan muka pelaku tutur yang diungkapkan oleh Brown dan Levinson (1987), yaitu setiap strategi bertutur memberikan sumbangan terhadap terbentuknya tingkat kesantunan berbahasa. Kesantunan tuturan yang tinggi dibentuk dengan menggunakan berbagai kesantunan berbahasa dalam sebuah tuturan.

Temuan ini mendukung hasil penelitian yang dilakukan oleh Ibrahim (1996), Mualimin (2003), Amir dan Ngusman (2006). Temuan dalam tulisan ini sama dengan hasil penelitian Ibrahim (1996), yaitu penutur cenderung menggunakan tuturan tidak langsung untuk meminimalkan beban dan paksaan kepada petutur agar tuturan dirasakan santun oleh petutur. Mualimin (2003) meneliti realisasi kesantunan direktif dalam surat bisnis berbahasa Inggris yang ditulis oleh orang Indonesia. Ada kesamaan temuan dalam tulisan ini dengan temuan dalam penelitian Mualimin, yaitu pemilihan strategi kesantunan terkait dengan risiko yang dapat ditimbulkan karena adanya perbedaan tingkat kekuasaan di antara penuturpetutur. Jika risiko keterancaman muka tinggi, digunakan strategi ungkapan yang relatif tidak langsung dan jika risiko tingkat keterancaman muka kecil, digunakan strategi yang relatif langsung. Strategi bertutur tidak langsung berdampak terhadap peminimalan paksaan pada petutur, sehingga tuturan itu dirasakan santun oleh petutur. Kesamaan temuan dalam tulisan ini 
dengan hasil penelitian Amir dan Ngusman (2006) adalah dalam konteks situasi tutur yang tingkat keterancaman muka tinggi, penutur cenderung memilih tuturan tidak langsung yang digunakan untuk meminimalkan beban dan paksaan kepada petutur, sehingga tuturan dirasakan santun oleh petutur. Peminimalan beban dan paksaan kepada petutur menimbulkan dampak pelunakan daya ilokusi sehingga tuturan dirasakan santun oleh petutur.

\section{Simpulan dan Saran}

\section{Simpulan}

Penutur bahasa Indonesia menggunakan strategi peminimalan beban dan peminimalan paksaan di dalam tuturan bahasa Indonesia untuk membentuk kesantunan berbahasa. Strategi peminimalan beban kepada petutur dilakukan dengan menggunakan ungkapan 'sedikit' dan 'sebentar' dalam tuturan. Strategi peminimalan paksaan dilakukan dengan menggunakan permintaan bersyarat, rumusan saran, harapan, dan pertanyaan. Penggunaan ungkapan 'sedikit' dan 'sebentar, permintaan bersyarat, rumusan saran, harapan, dan pertanyaan' menimbulkan efek pelunakan daya ilokusi, sehingga tuturan dirasakan santun oleh petutur.

Dalam sebuah tuturan, tidak hanya digunakan strategi peminimalan beban atau peminimalan paksaan, melainkan strategi itu digabungkan dengan strategi yang lain, misalnya permintaan maaf, penggunaan kata sapaan kekerabatan, alasan atau yang lain. Dalam konteks situasi tutur yang tingkat keterancaman muka tinggi (+K-S), cenderung digunakan tuturan yang banyak menggunakan peranti kesantunan berbahasa. Sebaliknya, dalam konteks situasi tutur yang tingkat keterancaman muka rendah ($\mathrm{K}+\mathrm{S})$, cenderung digunakan tuturan yang sedikit menggunakan peranti kesantunan berbahasa. Setiap strategi bertutur memberikan sumbangan terhadap terbentuknya tingkat kesantunan berbahasa. Kesantunan tuturan yang tinggi dibentuk dengan menggunakan berbagai kesantunan berbahasa dalam sebuah tuturan.

Dalam hubungannya dengan penelitian terdahulu yang terkait, temuan ini mendukung hasil penelitian yang dilakukan oleh Ibrahim (1996), Mualimin (2003), Amir dan Ngusman (2006). Temuan ini mengukuhkan teori kesantunan berbahasa Brown dan Levinson (1987) dan teori kesantunan berbahasa yang diungkapkan oleh Leech (1983). Dengan kata lain, teori kesantunan berbahasa Brown dan Levinson (1987) dan teori kesantunan berbahasa Leech (1983) didukung oleh data dalam bahasa Indonesia.

\section{Saran}

Hasil penelitian ini dapat dimanfaatkan dalam pembelajaran bahasa Indonesia terutama untuk keterampilan berbicara. Pembelajaran bahasa yang berorientasi pada target, yaitu siswa mahir berbahasa Indonesia dalam kehidupan sehari-hari memerlukan kajian pragmatik agar pembelajaran bahasa sesuai dengan konteks pemakaian bahasa dalam kehidupan sehari-hari.

\section{Pustaka Acuan}

Amir, Amril dan Ngusman Abdul Manaf. 2006. "Strategi Wanita Melindungi Citra Dirinya dan Citra Diri Orang Lain dalam Tuturan Bahasa Indonesia di Kalangan Anggota Kelompok Etnis Minangkabau di Padang". Laporan Hasil Penelitian. Padang: Lembaga Penelitian Universitas Negeri Padang.

Austin, J.L. 1962. How to Do Thing with Words. New York: Oxford University Press.

Brown, Penelope dan Stephen C. Levinson. 1987. Politeness: Some Universals in Language Usage. Cambridge: University of Cambridge Press.

Ibrahim, Syukur. 1996. "Bentuk Direktif Bahasa Indonesia". Disertasi. Surabaya: Universitas Erlangga. Leech, Geoffrey. 1983. Principles of Pragmatics. London: Longman.

Levinson, Stephen. 1983. Pragmatics. Cambridge: Cambridge University Press.

Mualimin. 2003. "Kesantunan Direktif dalam Surat Bisnis: Kajian Penggunaan Ungkapan Permohonan Bahasa Inggris oleh Penutur Bahasa Indonesia" di dalam Jurnal Bidang Kebahasaan, Kesusateraan, dan Kebudayaan, 27. 1: 11-19.

Searle, John R. 1976. "The Clasification of Ilucutionary Acts". Language and Society 5: 1-24. 